\title{
Alumina-Doped Silica Aerogels for High-Temperature Thermal Insulation
}

\author{
Yu Wu, Xiaodong Wang *D, Lin Liu, Ze Zhang and Jun Shen * \\ Shanghai Key Laboratory of Special Artificial Microstructure Materials and Technology, School of Physics Science \\ and Engineering, Tongji University, Shanghai 200092, China; 1410560@tongji.edu.cn (Y.W.); \\ 1930976@tongji.edu.cn (L.L.); zzzhangze@163.com (Z.Z.) \\ * Correspondence: xiaodong_wang@tongji.edu.cn (X.W.); shenjun67@tongji.edu.cn (J.S.)
}

Citation: Wu, Y.; Wang, X.; Liu, L.; Zhang, Z.; Shen, J. Alumina-Doped Silica Aerogels for High-Temperature Thermal Insulation. Gels 2021, 7, 122. https://doi.org/10.3390/gels7030122

Academic Editor: Luis Esquivias Fedriani

Received: 8 July 2021

Accepted: 12 August 2021

Published: 14 August 2021

Publisher's Note: MDPI stays neutral with regard to jurisdictional claims in published maps and institutional affiliations.

Copyright: (c) 2021 by the authors. Licensee MDPI, Basel, Switzerland. This article is an open access article distributed under the terms and conditions of the Creative Commons Attribution (CC BY) license (https:// creativecommons.org/licenses/by/ $4.0 /)$.

\begin{abstract}
In this study, we used two methods to prepare alumina-doped silica aerogels with the aim of increasing the thermal stability of silica aerogels. The first method was physical doping of $\alpha-\mathrm{Al}_{2} \mathrm{O}_{3}$ nano powders, and the second method was to create a chemical compound via the co-precursor of TEOS and $\mathrm{AlCl}_{3} \cdot 6 \mathrm{H}_{2} \mathrm{O}$ in different proportions. The shrinkage, chemical composition, and specific surface area (SSA) of samples after heating at different temperatures were analyzed. Our results show that the silicon hydroxyl groups of samples derived from $\mathrm{AlCl}_{3} \cdot 6 \mathrm{H}_{2} \mathrm{O}$ gradually decreased and nearly disappeared after heating at $800{ }^{\circ} \mathrm{C}$, which indicates the complete dehydration of the silicon hydroxyl. Thus, the samples exhibited a large linear shrinkage and decreased SSA after high-temperature heat treatment. By contrast, samples doped with $\alpha-\mathrm{Al}_{2} \mathrm{O}_{3}$ powders retained abundant silicon hydroxyl groups, and the $6.1 \mathrm{wt} . \% \alpha-\mathrm{Al}_{2} \mathrm{O}_{3}$-doped sample exhibited the lowest linear shrinkage of $11 \%$ and the highest SSA of $1056 \mathrm{~m}^{2} / \mathrm{g}$ after heat treatment at $800{ }^{\circ} \mathrm{C}$. The alumina-doped silica aerogels prepared using a simple and low-price synthesized method pave the way for the low-cost and large-scale production of high-temperature thermal insulation.
\end{abstract}

Keywords: silica aerogels; alumina-doped; high temperature resistance; thermal stability

\section{Introduction}

Silica aerogels are considered important and useful materials due to their nanoporous structure, ultra-low density, low thermal conductivity, high porosity and high specific surface area. Following about 90 years of development, the production of silica aerogels has been industrialized, and they have been widely applied, especially in the thermal insulation field [1-4]. Over recent years, research on silica aerogels and their composites has focused on synthesis parameters $[5,6]$, multivariate composites $[7,8]$, mechanical reinforcement $[9,10]$ and industrial applications [11,12]. Different silica aerogel composite materials, such as blankets, paint, coatings and cloth, have been applied in buildings, oil pipelines and as industry furnace insulation. However, pure silica aerogels sinter at temperatures above $600{ }^{\circ} \mathrm{C}$, which limits their high-temperature applications.

Metal oxides, such as $\mathrm{Al}_{2} \mathrm{O}_{3}$ [13-18], $\mathrm{ZrO}_{2}$ [19-22] and $\mathrm{TiO}_{2}$ [23-26]) aerogels, possess better thermal stability and thermal insulation properties than silica aerogels at temperatures above $600{ }^{\circ} \mathrm{C}$, especially alumina aerogels. For example, $\mathrm{Zu}$ et al. [27] prepared silica-doped alumina aerogels with high heat resistance, which showed a partial $\theta-\mathrm{Al}_{2} \mathrm{O}_{3}$ phase and a high SSA of $136 \mathrm{~m}^{2} / \mathrm{g}$ after heat treatment at $1300{ }^{\circ} \mathrm{C}$. However, the related research remains in the laboratory stage and depends on expensive raw materials and complex processes, making it difficult to carry out large-scale industrial production. Fabricating silica-based aerogels with enhanced heat resistance using an inexpensive process is critical to the development of industrial high-temperature applications. Preparing a silica-alumina composite aerogel represents a potentially effective method for enhancing the heat resistance of aerogels, but the specific synthesis methods (i.e., precursors, composite modes and sol-gel parameters) need to be studied. Currently, the precursors of 
alumina for aerogels mainly include aluminum alkoxides, such as aluminum sec-butoxide (ASB) or isopropoxide (AIP), and alumina inorganic salts such as aluminum chloride $\left(\mathrm{AlCl}_{3} \cdot 6 \mathrm{H}_{2} \mathrm{O}\right)$ and aluminum nitrate $\left(\mathrm{Al}\left(\mathrm{NO}_{3}\right)_{3} \cdot 9 \mathrm{H}_{2} \mathrm{O}\right)$. Although aluminum alkoxides are the main precursors used to fabricate alumina or alumina composite aerogels, they have some defects that render them unsuitable for industrial production. Aluminum alkoxides have ultra-high reactivity and complex chemical pathways; thus, the reaction process is difficult to control. Moreover, aluminum alkoxides are relatively expensive and are not environmentally friendly. By contrast, alumina inorganic salts are easily controlled during gel preparation and are more economical. Many strategies, including ion-exchange resin, electrosorption ion removal and inorganic ion exchanger [28-31] for chloride ion removal, have been developed. Wu et al. [32] fabricated $\mathrm{Al}_{2} \mathrm{O}_{3}-\mathrm{SiO}_{2}$ composite aerogels via TEOS and $\mathrm{AlCl}_{3} \cdot 6 \mathrm{H}_{2} \mathrm{O}$ as precursors, which showed a $\gamma-\mathrm{Al}_{2} \mathrm{O}_{3}$ phase and high SSA of $630.6 \mathrm{~m}^{2} / \mathrm{g}$ after heat treatment at $600{ }^{\circ} \mathrm{C}$. However, the SSA of $\mathrm{Al}_{2} \mathrm{O}_{3}-\mathrm{SiO}_{2}$ composite aerogels decreased to $277.7 \mathrm{~m}^{2} / \mathrm{g}$ due to volume shrinkage after heat treatment at $1000{ }^{\circ} \mathrm{C}$. Chen et al. [33] prepared $\mathrm{Al}_{2} \mathrm{O}_{3}-\mathrm{SiO}_{2}$ aerogels using TEOS and $\mathrm{AlCl}_{3} \cdot 6 \mathrm{H}_{2} \mathrm{O}$ as precursors and found that the samples with a molar ratio of $\mathrm{Al} / \mathrm{Si}=3: 1$ possessed better thermal insulation performance and thermal stability, but the alumina proportion was ultra-high, which was not suitable for industrial-scale production. Lei et al. [34] improved the thermal insulation of silica aerogels doped with nano-size $\mathrm{Al}_{2} \mathrm{O}_{3}$ powders. They found that the macropore volume fraction was dramatically reduced from $63.05 \%$ to $23.12 \%$, and that the SSA decreased from $837.4 \mathrm{~m}^{2} / \mathrm{g}$ to $358.5 \mathrm{~m}^{2} / \mathrm{g}$ with the addition of $\mathrm{Al}_{2} \mathrm{O}_{3}$ powders at room temperature; however, they did not mention its high-temperature properties. As using alumina inorganic salts is preferable for industrial production, we selected $\mathrm{AlCl}_{3} \cdot 6 \mathrm{H}_{2} \mathrm{O}$ and $\alpha-\mathrm{Al}_{2} \mathrm{O}_{3}$ powders as the raw materials in low proportions to improve the hightemperature performance of silica aerogels and examined the feasibility of this method for large-scale production.

In this paper, we present an acid-base, two-step sol-gel method for the synthesis of monolithic alumina-doped silica aerogels using $\mathrm{AlCl}_{3} \cdot 6 \mathrm{H}_{2} \mathrm{O}$ and $\alpha-\mathrm{Al}_{2} \mathrm{O}_{3}$ powders as the raw materials. We applied two composite methods: Physical doping of $\alpha-\mathrm{Al}_{2} \mathrm{O}_{3}$ nano powders and creating a chemical compound through the co-precursor of tetraethyl orthosilicate (TEOS) and $\mathrm{AlCl}_{3} \cdot 6 \mathrm{H}_{2} \mathrm{O}$ in low proportions. These methods are low-cost and environmentally friendly as they lack alumina alkoxides and epoxide addition. Furthermore, these methods may promote the industrialization of silica-based aerogels in the application of high-temperature $\left(600-1000^{\circ} \mathrm{C}\right)$ thermal insulation.

\section{Results and Discussion}

\subsection{Macroscopic Properties of As-Prepared Samples}

Figure 1 shows the macro-morphology of the as-prepared samples. After supercritical drying, both methods obtained semitransparent, monolithic and crack-free alumina-doped silica aerogels. The AL samples exhibited lower density and thermal conductivity than the AO samples with the same molar percentage (Table 1), and AL4 had the lowest thermal conductivity of $0.0269 \mathrm{~W} / \mathrm{m} \cdot \mathrm{K}$.

After heat treatment at $1000{ }^{\circ} \mathrm{C}$ for $1 \mathrm{~h}$, most samples retained a monolithic and crackfree macro-morphology as depicted in Figure 2. AO samples were white in color throughout the heating process. By contrast, the color of AL samples changed from brown to white as the temperature increased from $500{ }^{\circ} \mathrm{C}$ to $700{ }^{\circ} \mathrm{C}$, which indicates the decomposition of organic groups. The density and thermal conductivity at room temperature of all samples after annealing at $1000{ }^{\circ} \mathrm{C}$ are listed in Table 2 . The increase in density and thermal conductivity of $\mathrm{AO}$ samples after heating at $1000{ }^{\circ} \mathrm{C}$ was smaller than for AL samples. AL7 and AL10, in particular, exhibited a high density and thermal conductivity after heat treatment at $1000^{\circ} \mathrm{C}$. Nevertheless, $\mathrm{AO}$ and AL samples exhibited broadly similar thermal stability, although AL4 had the lowest density $\left(234 \mathrm{mg} / \mathrm{cm}^{3}\right)$ and thermal conductivity $(0.050 \mathrm{~W} / \mathrm{m} \cdot \mathrm{K})$ after calcination at $1000^{\circ} \mathrm{C}$. 


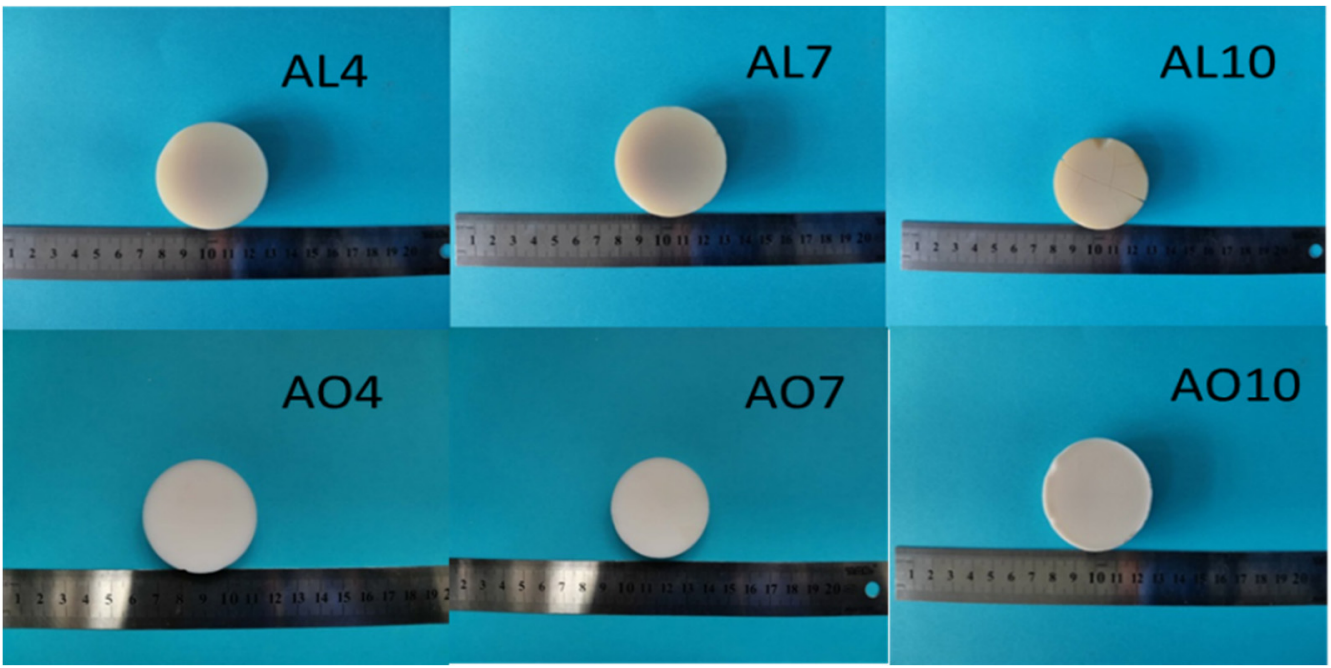

Figure 1. Photos of alumina-doped silica aerogels formed with different precursors and proportions without heat treatment ( $\mathrm{AL}$ and $\mathrm{AO}$ represent the samples derived from $\mathrm{AlCl}_{3} \cdot 6 \mathrm{H}_{2} \mathrm{O}$ and $\alpha-\mathrm{Al}_{2} \mathrm{O}_{3}$ powders, respectively. The numbers denote the molar percentage of $\mathrm{Al} /(\mathrm{Al}+\mathrm{Si}))$.

Table 1. Density and room-temperature thermal conductivity (measured by the hotdisk method) of different samples without heat treatment ( $\mathrm{AL}$ and $\mathrm{AO}$ represent the samples derived from $\mathrm{AlCl}_{3} \cdot 6 \mathrm{H}_{2} \mathrm{O}$ and $\alpha-\mathrm{Al}_{2} \mathrm{O}_{3}$ powders, respectively. The numbers denote the molar percentage of $\mathrm{Al} /(\mathrm{Al}+\mathrm{Si}))$.

\begin{tabular}{|c|c|c|c|c|c|}
\hline Sample & $\begin{array}{c}\text { Density } \\
\left(\mathrm{mg} / \mathrm{cm}^{3}\right)\end{array}$ & $\begin{array}{c}\text { Thermal } \\
\text { Conductivity } \\
(\mathrm{W} / \mathrm{m} \cdot \mathrm{K})\end{array}$ & Sample & $\begin{array}{c}\text { Density } \\
\left(\mathrm{mg} / \mathrm{cm}^{3}\right)\end{array}$ & $\begin{array}{c}\text { Thermal } \\
\text { Conductivity } \\
(\mathrm{W} / \mathrm{m} \cdot \mathrm{K})\end{array}$ \\
\hline AO0.5 & 151 & $0.0383 \pm 0.0019$ & $\mathrm{SiO}_{2}$ & 132 & $0.0286 \pm 0.0014$ \\
\hline $\mathrm{AO} 1$ & 149 & $0.0374 \pm 0.0020$ & AL1 & 134 & $0.0283 \pm 0.0016$ \\
\hline $\mathrm{AO} 2$ & 155 & $0.0340 \pm 0.0017$ & AL2 & 140 & $0.0296 \pm 0.0015$ \\
\hline $\mathrm{AO} 4$ & 161 & $0.0360 \pm 0.0019$ & AL4 & 114 & $0.0269 \pm 0.0014$ \\
\hline AO7 & 170 & $0.0357 \pm 0.0018$ & AL7 & 102 & $0.0284 \pm 0.0014$ \\
\hline AO10 & 144 & $0.0304 \pm 0.0015$ & AL10 & 103 & $0.0292 \pm 0.0015$ \\
\hline
\end{tabular}

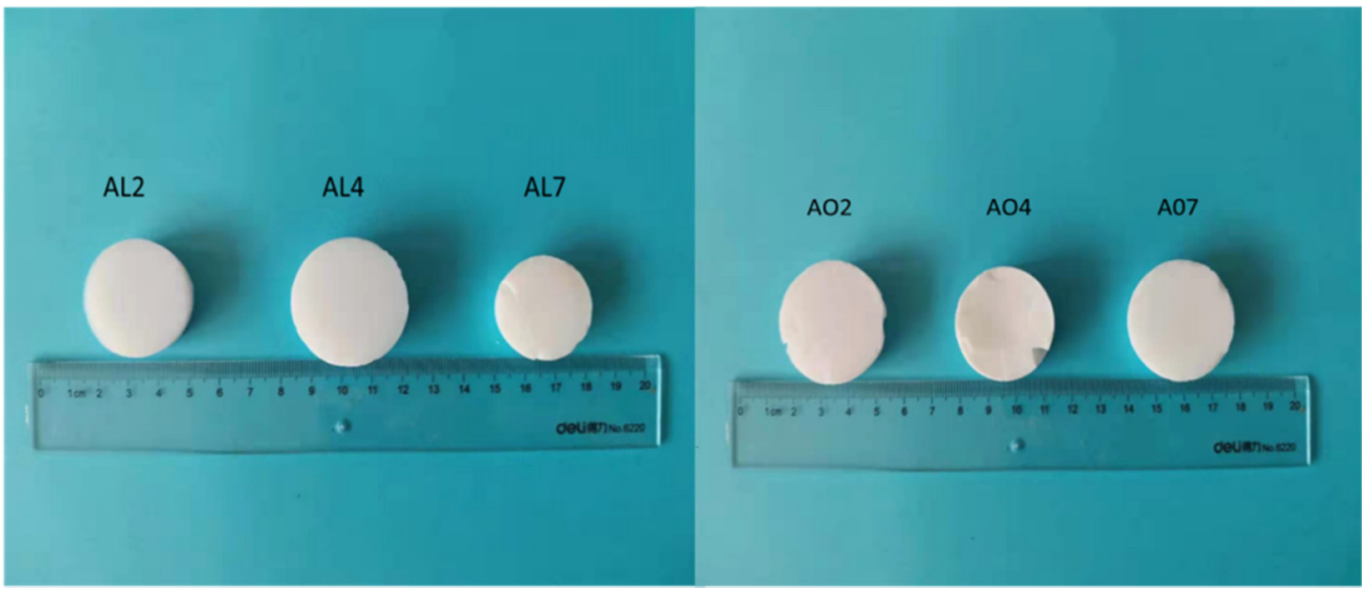

Figure 2. Photos of alumina-doped silica aerogels after heat treatment at $1000{ }^{\circ} \mathrm{C}(\mathrm{AL}$ and $\mathrm{AO}$ represent the samples derived from $\mathrm{AlCl}_{3} \cdot 6 \mathrm{H}_{2} \mathrm{O}$ and $\alpha-\mathrm{Al}_{2} \mathrm{O}_{3}$ powders, respectively. The numbers denote the molar percentage of $\mathrm{Al} /(\mathrm{Al}+\mathrm{Si}))$. 
Table 2. Density and room-temperature thermal conductivity (measured by hotdisk method) of different samples after heat treatment at $1000{ }^{\circ} \mathrm{C}$ (AL and $\mathrm{AO}$ represent the samples derived from $\mathrm{AlCl}_{3} \cdot 6 \mathrm{H}_{2} \mathrm{O}$ and $\alpha-\mathrm{Al}_{2} \mathrm{O}_{3}$ powders, respectively. The numbers denote the molar percentage of $\mathrm{Al} /(\mathrm{Al}+\mathrm{Si}))$.

\begin{tabular}{cccccc}
\hline Sample & $\begin{array}{c}\text { Density } \\
\left(\mathbf{m g} / \mathbf{c m}^{\mathbf{3}}\right)\end{array}$ & $\begin{array}{c}\text { Thermal } \\
\text { Conductivity } \\
\mathbf{( W / m} \cdot \mathbf{K})\end{array}$ & Sample & $\begin{array}{c}\text { Density } \\
\left(\mathbf{m g} / \mathbf{c m}^{\mathbf{3}} \mathbf{)}\right.\end{array}$ & $\begin{array}{c}\text { Thermal } \\
\text { Conductivity } \\
\mathbf{( W / m} \cdot \mathbf{K})\end{array}$ \\
\hline $\mathrm{AO1}$ & 273 & $0.058 \pm 0.003$ & AL1 & 334 & $0.057 \pm 0.003$ \\
$\mathrm{AO} 2$ & 277 & $0.054 \pm 0.003$ & AL2 & 299 & $0.056 \pm 0.003$ \\
$\mathrm{AO} 4$ & 315 & $0.056 \pm 0.003$ & AL4 & 234 & $0.050 \pm 0.003$ \\
$\mathrm{AO} 7$ & 280 & $0.055 \pm 0.003$ & AL7 & 409 & $0.067 \pm 0.003$ \\
$\mathrm{AO} 10$ & 314 & $0.056 \pm 0.003$ & AL10 & 331 & $0.062 \pm 0.003$ \\
\hline
\end{tabular}

Figures 3 and 4 exhibit the variation in the microstructures of samples AL7 and AO7 after heat treatment from $300{ }^{\circ} \mathrm{C}$ to $900{ }^{\circ} \mathrm{C}$. Sample AL7 maintained a uniform nanoporous structure, and no apparent pore structure collapse was observed after high temperature calcination, which resulted in the low shrinkage shown in Figure 5. On the contrary, sample AO7 showed a comparatively denser pore structure that became denser and sintered as the calcination temperature increased. These results indicate that the AL sample possesses better thermal stability than the AO sample.

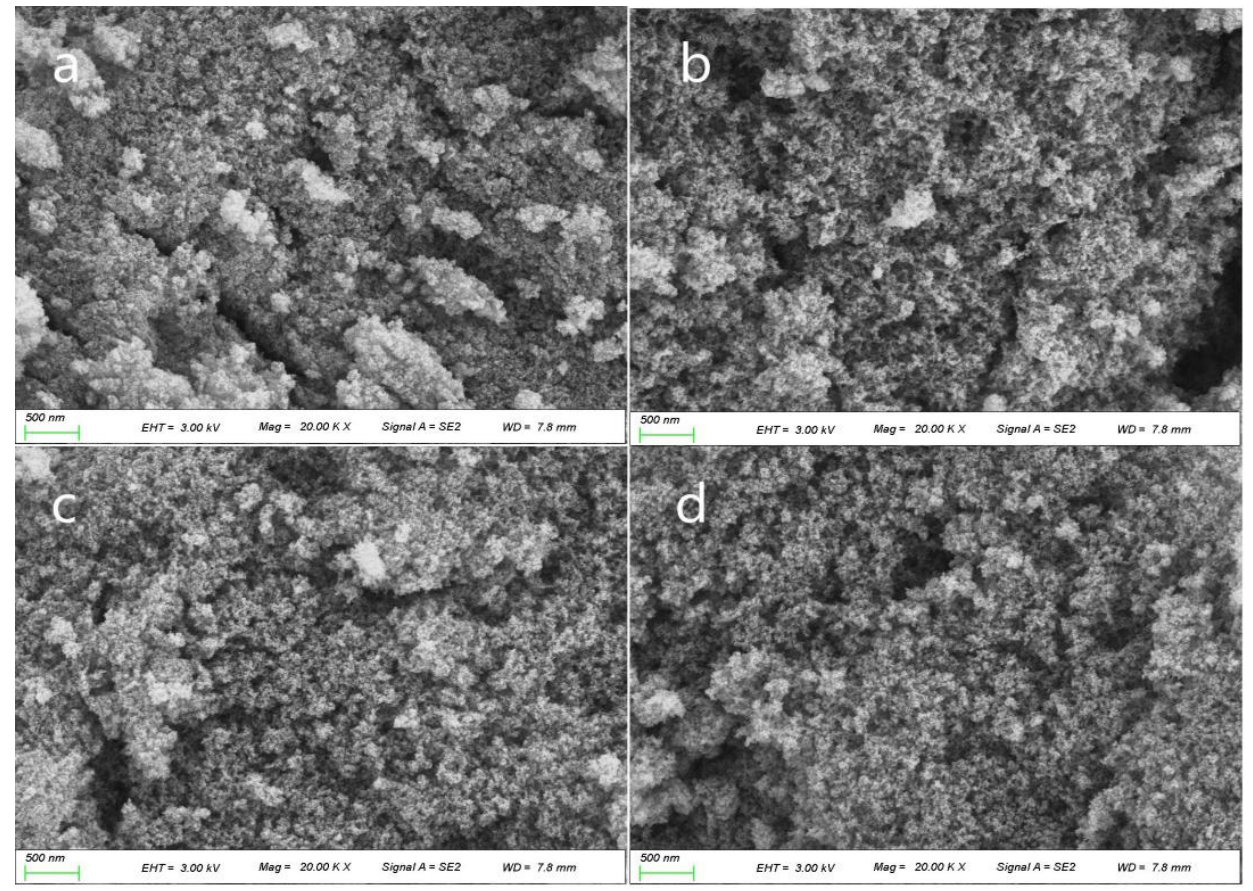

Figure 3. Scanning electron microscopy (SEM) images of sample AL7 after heat treatment from 300 to $900{ }^{\circ} \mathrm{C}$ : (a) AL7-300, (b) AL7-500, (c) AL7-700 and (d) AL7-900 (EHT: extra high tension, MAG: magnification, SE: secondary electrons, WD: work distance). 


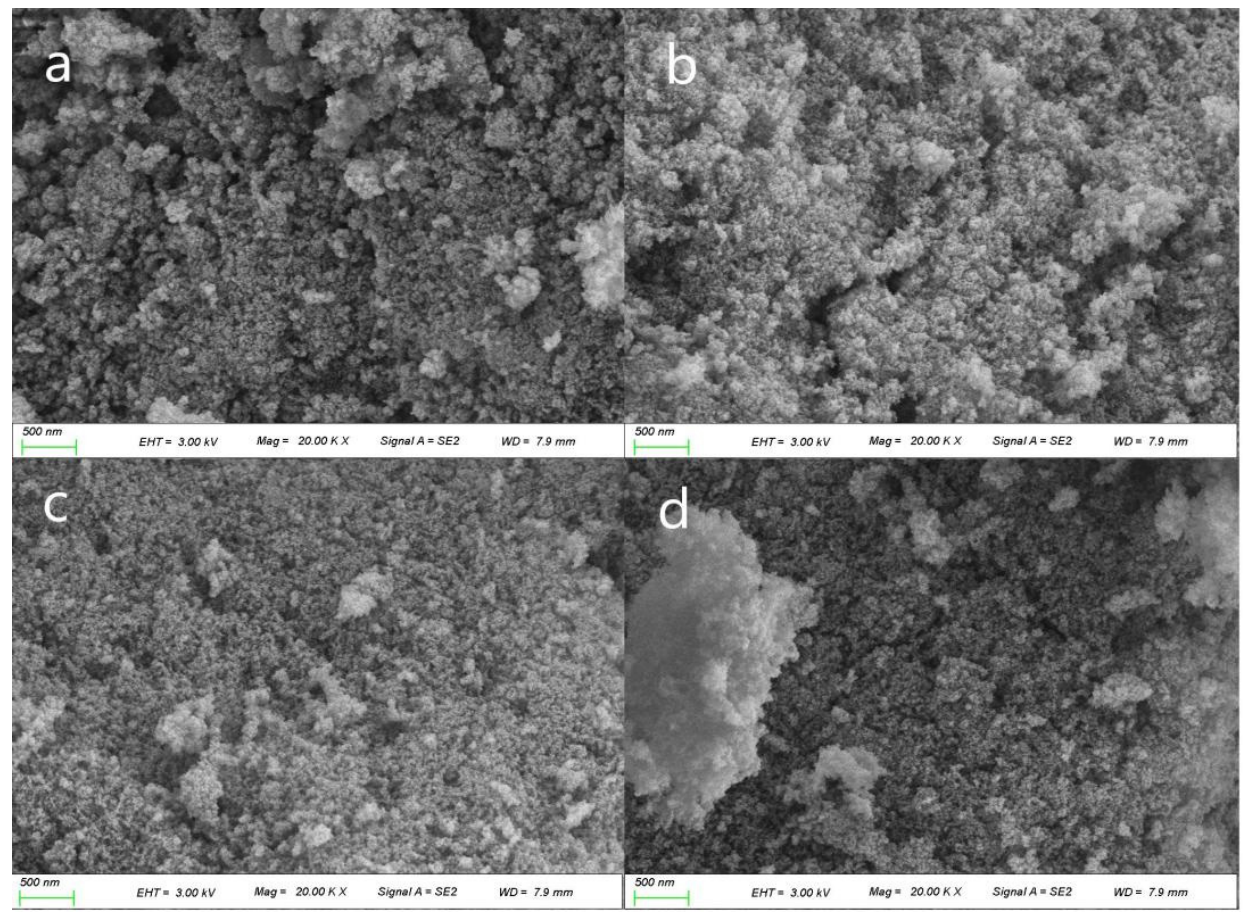

Figure 4. Scanning electron microscopy (SEM) images of AO7 sample after heat treatment from 300 to $900{ }^{\circ} \mathrm{C}$ : (a) AO7-300, (b) AO7-500, (c) AO7-700 and (d) AO7-900 (EHT: extra high tension, MAG: magnification, SE: secondary electrons, WD: work distance).
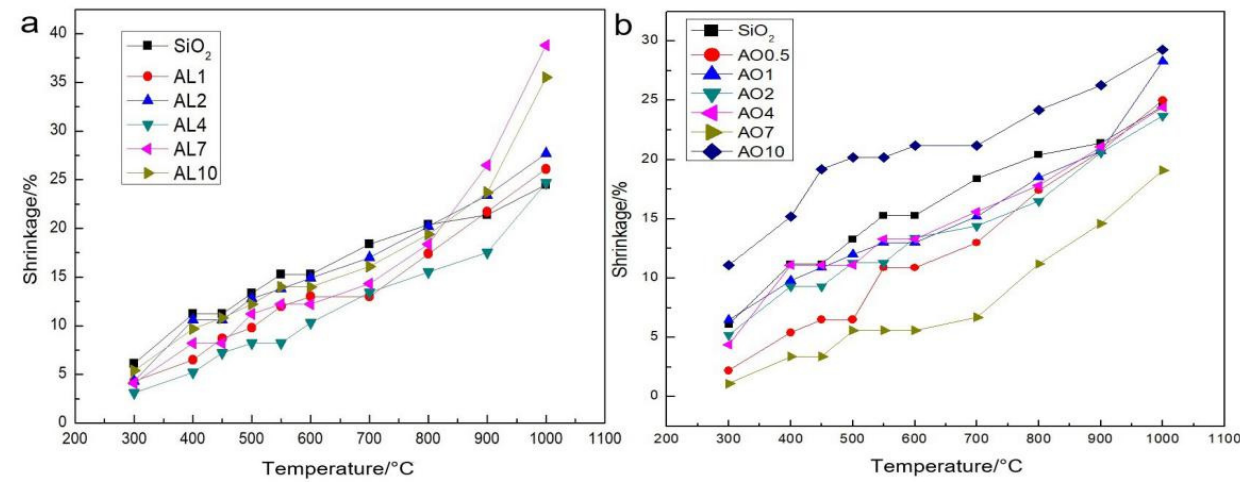

Figure 5. The linear shrinkage of (a) AL samples and (b) AO samples after heat treatments from 300 to $1000{ }^{\circ} \mathrm{C}$ (AL and $\mathrm{AO}$ represent the samples derived from $\mathrm{AlCl}_{3} \cdot 6 \mathrm{H}_{2} \mathrm{O}$ and $\alpha-\mathrm{Al}_{2} \mathrm{O}_{3}$ powders, respectively. The numbers denote the molar percentage of $\mathrm{Al} /(\mathrm{Al}+\mathrm{Si}))$.

\subsection{Shrinkage after Different Heating Temperatures}

In order to analyze the thermal stability of samples, we focused on the linear shrinkage of all the samples after heat treatment from 300 to $1000{ }^{\circ} \mathrm{C}$ with an incremental step of $100{ }^{\circ} \mathrm{C}$ (Figure 5). As the temperature increased from 400 to $600{ }^{\circ} \mathrm{C}$ the incremental rise was $50{ }^{\circ} \mathrm{C}$ because of the potentially drastic change in aerogel structure over this temperature range. For AL samples, all alumina-doped silica aerogels exhibited lower linear shrinkage compared with pure silica aerogels after heat treatment before $800{ }^{\circ} \mathrm{C}$. However, after heat treatment at 900 and $1000{ }^{\circ} \mathrm{C}$, alumina-doped silica aerogels showed a large increase in linear shrinkage, especially samples AL7 and AL10. As the AL4 sample had the best thermal stability, it was selected for detailed study. Most AO samples exhibited lower linear shrinkage compared with pure silica aerogels. Moreover, there was no large increment of linear shrinkage from 900 to $1000{ }^{\circ} \mathrm{C}$ due to the stable crystal phase of $\alpha-\mathrm{Al}_{2} \mathrm{O}_{3}$. By comparing the two figures, we found that AL samples exhibit lower linear shrinkage before 
calcination at $800^{\circ} \mathrm{C}$, while $\mathrm{AO}$ samples show lower linear shrinkage after calcination at $800^{\circ} \mathrm{C}$.

\subsection{Variation of Chemical Composition at Different Temperatures}

Figure 6 shows the variation in chemical bonds of the AL4 and AO samples after heat treatment at different temperatures. With regard to the FTIR spectra of sample AL4 after heat treatment from 300 to $1000{ }^{\circ} \mathrm{C}$, bands at 3450 and $1638 \mathrm{~cm}^{-1}$ indicate the presence of water adsorption [35]. The wide band at $1095 \mathrm{~cm}^{-1}$ corresponds to an antisymmetric stretching vibration peak of $\mathrm{Si}-\mathrm{O}-\mathrm{Si}$, and the bands at 798 and $466 \mathrm{~cm}^{-1}$ correspond to a symmetric stretching vibration peak of $\mathrm{Si}-\mathrm{O}-\mathrm{Si}$. These bands do not show significant changes with the increment of temperature. The bands at 2972,2898 and $1402 \mathrm{~cm}^{-1}$ at under $400{ }^{\circ} \mathrm{C}$ indicate the $\mathrm{Si}-\mathrm{CH}_{3}$ vibration of hydrocarbon groups and disappear after heat treatment at over $500{ }^{\circ} \mathrm{C}$. The band at $955 \mathrm{~cm}^{-1}$, which is related to a bending vibration peak of $\mathrm{Si}-\mathrm{OH}$, decreases gradually with the increment of temperature and completely disappears after heat treatment at $800{ }^{\circ} \mathrm{C}$. This result indicates a dehydration reaction of $\mathrm{Si}-\mathrm{OH}$ that results in significant linear shrinkage. For the FTIR spectra of the AO and AL samples after heat treatment at $800{ }^{\circ} \mathrm{C}$, the main peaks were related to water adsorption and the $\mathrm{Si}-\mathrm{O}-\mathrm{Si}$ bond, which are similar to the results for the AL4 sample. However, the band at $955 \mathrm{~cm}^{-1}$ relating to $\mathrm{Si}-\mathrm{OH}$ reveals different conditions. The peak related to the $\mathrm{Si}-\mathrm{OH}$ bond of AL samples almost disappears, except for in sample AL2, while the $\mathrm{Si}-\mathrm{OH}$ bond of all the $\mathrm{AO}$ samples still existed after heat treatment at $800{ }^{\circ} \mathrm{C}$, which resulted in a reduced linear shrinkage compared to all the AL samples. The Al-O-Al and AL-OH bonds at 880 and $1074 \mathrm{~cm}^{-1}[36,37]$ were not observed in the FTIR spectra due to the relatively rare doping content of alumina.
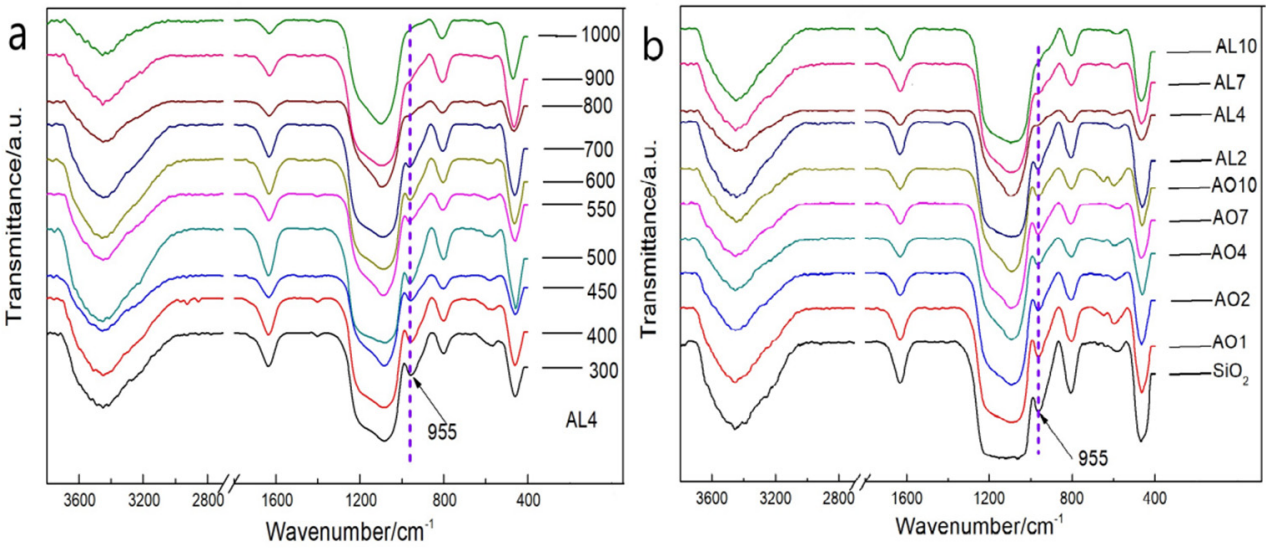

Figure 6. FTIR spectra of the (a) AL4 after heat treatment from 300 to $1000{ }^{\circ} \mathrm{C}$, and FTIR spectra of the (b) $\mathrm{AO}$ and $\mathrm{AL}$ samples after heat treatment at $800^{\circ} \mathrm{C}(\mathrm{AL}$ and $\mathrm{AO}$ represent the samples derived from $\mathrm{AlCl}_{3} \cdot 6 \mathrm{H}_{2} \mathrm{O}$ and $\alpha-\mathrm{Al}_{2} \mathrm{O}_{3}$ powders, respectively. The numbers denote the molar percentage of $\mathrm{Al} /(\mathrm{Al}+\mathrm{Si}))$.

\subsection{Crystal Phase of Aerogels after Heat Treatment at $800^{\circ} \mathrm{C}$}

Figure 7 shows the XRD pattern of $\mathrm{AO}$ and $\mathrm{AL}$ samples after heat treatment at $800{ }^{\circ} \mathrm{C}$. All AO samples show diffraction peaks at $25.6^{\circ}, 35.1^{\circ}, 37.8^{\circ}, 43.4^{\circ}, 52.5^{\circ}, 57.5^{\circ}, 66.5^{\circ}$ and $68.2^{\circ}$, which correspond to the $\alpha-\mathrm{Al}_{2} \mathrm{O}_{3}$ phase (PDF 10-0173). This was expected because the $\mathrm{AO}$ samples were doped with $\alpha-\mathrm{Al}_{2} \mathrm{O}_{3}$ powders. However, no AL samples exhibited a diffraction peak, indicating that the abundant silica content inhibited the phase transition of alumina. 

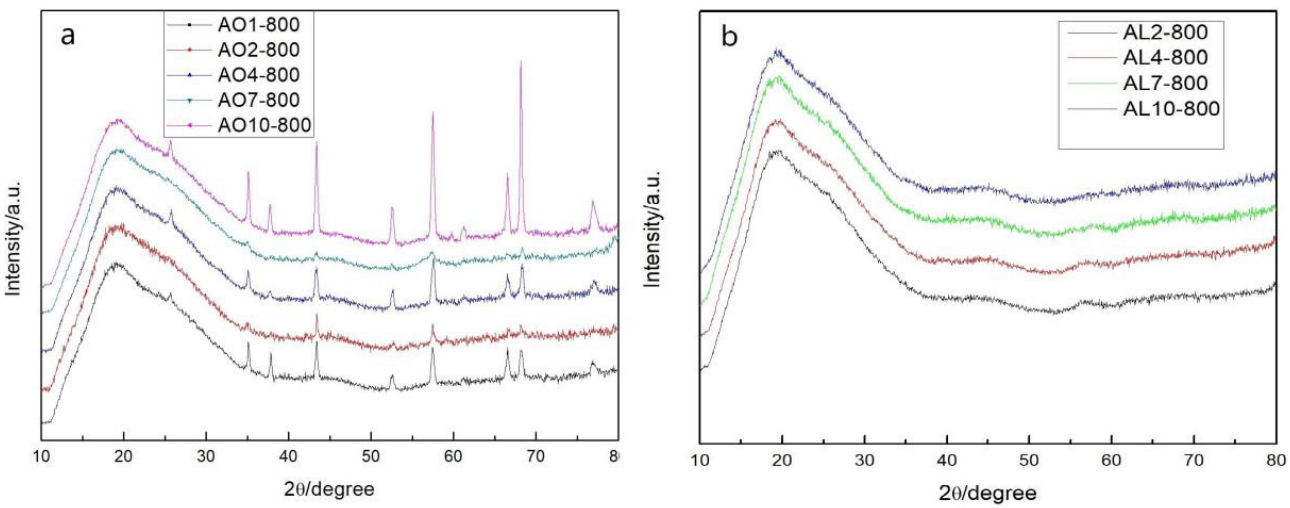

Figure 7. XRD patterns of (a) AO and (b) AL samples after heat treatment at $800{ }^{\circ} \mathrm{C}$ ( $\mathrm{AL}$ and $\mathrm{AO}$ represent the samples derived from $\mathrm{AlCl}_{3} \cdot 6 \mathrm{H}_{2} \mathrm{O}$ and $\alpha-\mathrm{Al}_{2} \mathrm{O}_{3}$ powders, respectively. The numbers denote the molar percentage of $\mathrm{Al} /(\mathrm{Al}+\mathrm{Si}))$.

\subsection{SSA and Pore Size Distribution at Different Temperatures}

Figure 8 shows desorption isotherms and the pore size distribution of sample AL4. All samples exhibit the characteristic features of mesoporous materials (Type-IV isotherms). The pore structure and pore size distribution show nearly no change with the incremental increase in temperature from 300 to $1000{ }^{\circ} \mathrm{C}$, which indicates high thermal stability. The specific data and variation tendencies are shown in Table 3 and Figure 9. It is obvious that the SSA of AL4 increases gradually before $550{ }^{\circ} \mathrm{C}$ and then decreases rapidly after $550{ }^{\circ} \mathrm{C}$, which can be attributed to the decomposition of residual organic groups. This can be identified by the color change from brown to white of the AL4 sample after heating. The average pore diameter of AL4 increased generally, which indicates the irreversible collapse of the mesoporous structure. The change in SSA and average pore diameter was also relatively small before $800{ }^{\circ} \mathrm{C}$. However, the SSA decreased significantly after heat treatment from 800 to $1000{ }^{\circ} \mathrm{C}$. This result can be mainly attributed to a dehydration reaction of $\mathrm{Si}-\mathrm{OH}$.
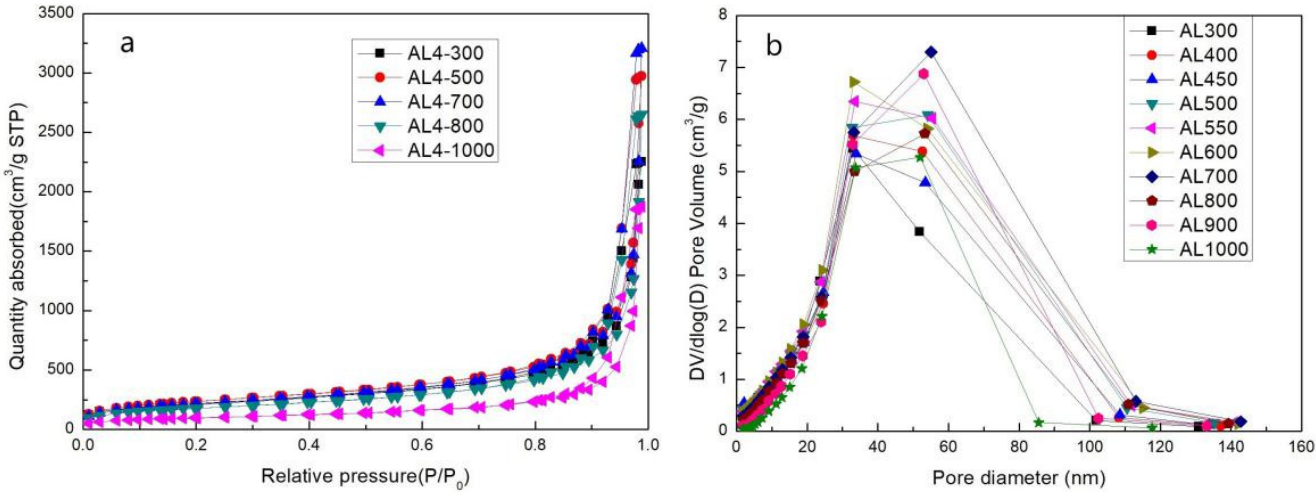

Figure 8. (a) Desorption isotherms and (b) pore size distribution of sample AL4 after heat treatment from 300 to $1000^{\circ} \mathrm{C}$.

Since the AL4 sample showed good thermal stability after being heat treated at $800{ }^{\circ} \mathrm{C}$, we studied the properties of other samples after heat treatment at $800{ }^{\circ} \mathrm{C}$. Figure 10 exhibits the Type-IV isotherms and mesoporous structure for all $\mathrm{AO}$ and $\mathrm{AL}$ samples. The pore diameter distributions of all samples show similar shapes, with only one peak, and the exact values are shown in Table 4. For AL samples, the SSA decreased gradually with the incremental rise of the proportion of alumina. The main reason for this is the dehydration reaction of $\mathrm{Si}-\mathrm{OH}$, as the hydrolysis of $\mathrm{AlCl}_{3} \cdot 6 \mathrm{H}_{2} \mathrm{O}$ produces abundant bonds of Al-OH. For AO samples, the situation differed: The addition of $\alpha-\mathrm{Al}_{2} \mathrm{O}_{3}$ powders reduced the dehydration reaction of $\mathrm{Si}-\mathrm{OH}$, increasing the SSA and decreasing the average 
pore diameter of $\mathrm{AO}$ samples. The AO7 sample, in particular, showed the highest SSA of $1056 \mathrm{~m}^{2} / \mathrm{g}$, which is consistent with the lowest linear shrinkage of $11 \%$.

Table 3. Specific surface area (SSA) and average pore diameter of sample AL4.

\begin{tabular}{|c|c|c|c|}
\hline Sample & $\begin{array}{c}\text { SSA } \\
\left(\mathrm{m}^{2} / \mathrm{g}\right)\end{array}$ & $\begin{array}{l}\text { Pore Diameter } \\
(\mathrm{nm})\end{array}$ & $\begin{array}{l}\text { Pore Volume } \\
\left(\mathrm{cm}^{3} / \mathrm{g}\right)\end{array}$ \\
\hline AL4-300 & $787 \pm 3$ & 18.9 & 3.5 \\
\hline AL4-400 & $827 \pm 3$ & 21.4 & 4.1 \\
\hline AL4-450 & $837 \pm 3$ & 20.2 & 3.9 \\
\hline AL4-500 & $862.8 \pm 1.9$ & 21.5 & 4.6 \\
\hline AL4-550 & $873.5 \pm 1.3$ & 21.4 & 4.8 \\
\hline AL4-600 & $851.5 \pm 1.3$ & 21.4 & 4.8 \\
\hline AL4-700 & $791.8 \pm 1.2$ & 23.6 & 5.0 \\
\hline AL4-800 & $650.3 \pm 1.0$ & 23.6 & 4.1 \\
\hline AL4-900 & $530.6 \pm 0.8$ & 28.0 & 4.2 \\
\hline AL4-1000 & $360.2 \pm 0.6$ & 28.8 & 2.9 \\
\hline
\end{tabular}
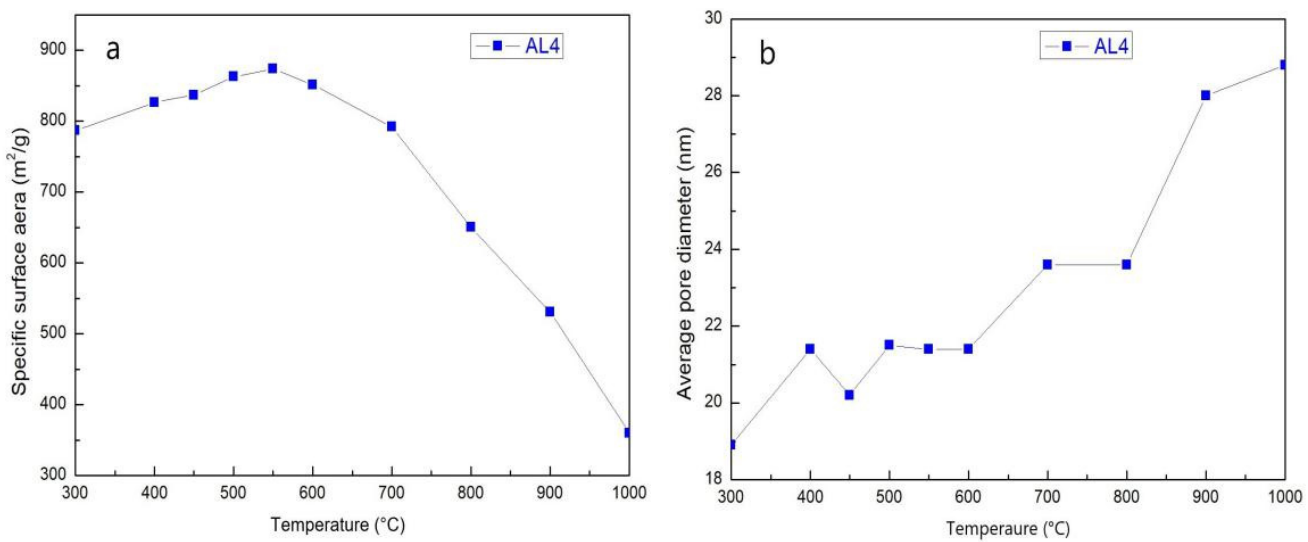

Figure 9. (a) Specific surface area (SSA) variation and (b) average pore diameter of sample AL4 with heat treatment from 300 to $1000^{\circ} \mathrm{C}$.

\subsection{Analysis of Sol-Gel Process and Thermal Stability}

The sol-gel process is the key step when constructing a robust three-dimensional network of aerogels and can be divided into the hydrolysis and condensation stage. For AL samples during the hydrolysis stage, we adjusted the $\mathrm{pH}$ value to $1-2$ by using $\mathrm{HNO}_{3}$. TEOS, ethanol, deionized water and $\mathrm{AlCl}_{3} \cdot 6 \mathrm{H}_{2} \mathrm{O}$ reacted according to Equations (1) and (2) and formed abundant $\mathrm{Si}-\mathrm{OH}$ and $\mathrm{Al}-\mathrm{OH}$ bonds. During the condensation stage, we adjusted the $\mathrm{pH}$ value of the solution to 6-7 using $\mathrm{NH}_{4} \mathrm{OH}$. Then, $\mathrm{Si}-\mathrm{OH}$ and $\mathrm{Al}-\mathrm{OH}$ bonds reacted according to Equations (3)-(5) and formed abundant $\mathrm{Si}-\mathrm{O}-\mathrm{Si}, \mathrm{Al}-\mathrm{O}-\mathrm{Al}$ and $\mathrm{Si}-\mathrm{O}-\mathrm{Al}$ bonds. There were also residual -OH bonds, especially on the surface of aerogels, which react more at high temperatures. For AO samples, TEOS has the same reactions while $\alpha-\mathrm{Al}_{2} \mathrm{O}_{3}$ powders are chemically stable. As the nanoparticles of $\alpha-\mathrm{Al}_{2} \mathrm{O}_{3}$ powders have high surface activity, silica primary particles will aggregate on the surface of $\alpha-\mathrm{Al}_{2} \mathrm{O}_{3}$ particles through van der Waals forces, the electrostatic force and hydrogen bonding [38]. 

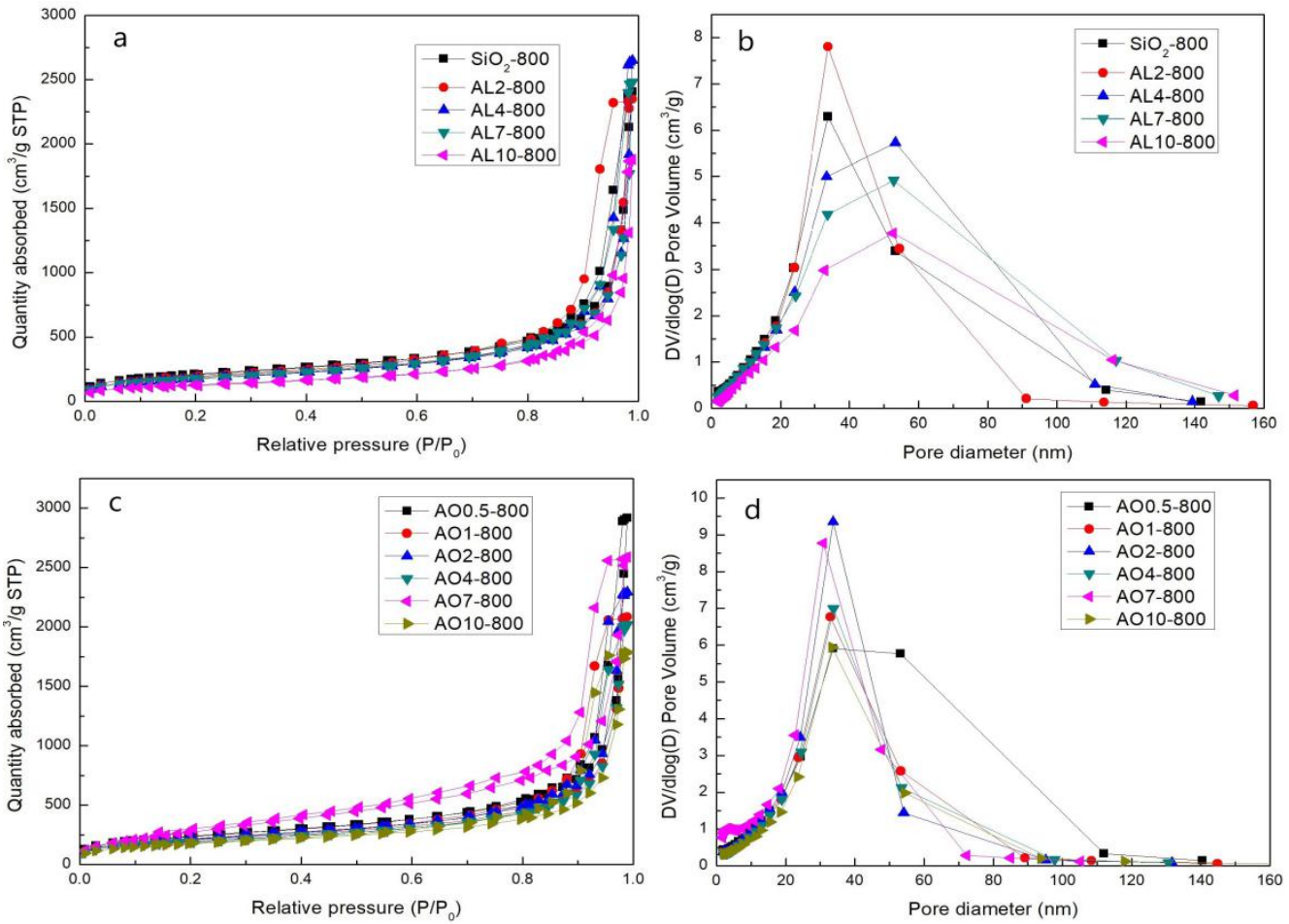

Figure 10. Desorption isotherms and pore size distribution of the (a,b) AL samples and (c,d) AO samples after heat treatment at $800{ }^{\circ} \mathrm{C}$ ( $\mathrm{AL}$ and $\mathrm{AO}$ represent the samples derived from $\mathrm{AlCl}_{3} \cdot 6 \mathrm{H}_{2} \mathrm{O}$ and $\alpha-\mathrm{Al}_{2} \mathrm{O}_{3}$ powders, respectively. The numbers denote the molar percentage of $\mathrm{Al} /(\mathrm{Al}+\mathrm{Si})$ ).

Table 4. Specific surface area (SSA) and average pore diameter of AL and AO samples after heat treatment at $800{ }^{\circ} \mathrm{C}\left(\mathrm{AL}\right.$ and $\mathrm{AO}$ represent the samples derived from $\mathrm{AlCl}_{3} \cdot 6 \mathrm{H}_{2} \mathrm{O}$ and $\alpha-\mathrm{Al}_{2} \mathrm{O}_{3}$ powders, respectively. The numbers denote the molar percentage of $\mathrm{Al} /(\mathrm{Al}+\mathrm{Si})$ ).

\begin{tabular}{|c|c|c|c|}
\hline Sample & $\operatorname{SSA}\left(\mathrm{m}^{2} / \mathrm{g}\right)$ & $\begin{array}{l}\text { Pore Dimeter } \\
\text { (nm) }\end{array}$ & $\begin{array}{l}\text { Pore Volumes } \\
\qquad\left(\mathrm{cm}^{3} / \mathrm{g}\right)\end{array}$ \\
\hline AL2 & $683.9 \pm 1.1$ & 20.5 & 3.7 \\
\hline AL4 & $650.3 \pm 1.0$ & 23.6 & 4.1 \\
\hline AL7 & $652.5 \pm 0.9$ & 21.8 & 3.9 \\
\hline AL10 & $471.9 \pm 0.7$ & 22.2 & 2.9 \\
\hline AO0.5 & $871.9 \pm 1.7$ & 20.9 & 4.5 \\
\hline AO1 & $743.4 \pm 1.7$ & 17.8 & 3.3 \\
\hline $\mathrm{AO} 2$ & $786.0 \pm 1.3$ & 18.0 & 3.6 \\
\hline $\mathrm{AO} 4$ & $706.3 \pm 1.3$ & 17.9 & 3.2 \\
\hline AO7 & $1056 \pm 12$ & 12.2 & 4.0 \\
\hline AO10 & $633.0 \pm 1.4$ & 17.9 & 2.8 \\
\hline
\end{tabular}

The specific sol-gel mechanism can be described by Equations (1)-(5) [18].

(a) Hydrolysis.

$$
\begin{gathered}
\mathrm{Si}\left(\mathrm{OC}_{2} \mathrm{H}_{5}\right)_{4}+n \mathrm{H}_{2} \mathrm{O} \rightarrow \mathrm{Si}(\mathrm{OH})_{n}\left(\mathrm{OC}_{2} \mathrm{H}_{5}\right)_{4-n}+n \mathrm{C}_{2} \mathrm{H}_{5} \mathrm{OH} \\
\mathrm{Al}_{3}{ }^{+}+6 \mathrm{H}_{2} \mathrm{O} \rightarrow\left[\mathrm{Al}\left(\mathrm{H}_{2} \mathrm{O}\right)_{6}\right]^{3+} \rightarrow\left[\mathrm{Al}(\mathrm{OH})_{n}\left(\mathrm{H}_{2} \mathrm{O}\right)_{6-n}\right]^{(3-\mathrm{n})+}+n \mathrm{H}^{+}
\end{gathered}
$$

(b) Condensation.

$$
\begin{gathered}
-\mathrm{Si}-\mathrm{OH}+\mathrm{Si}(\mathrm{OH})_{n}\left(\mathrm{OC}_{2} \mathrm{H}_{5}\right)_{4-n}->-\mathrm{Si}-\mathrm{O}-\mathrm{Si}(\mathrm{OH})_{n}\left(\mathrm{OC}_{2} \mathrm{H}_{5}\right)_{4-n}+\mathrm{H}_{2} \mathrm{O} \\
-\mathrm{Si}-\mathrm{OH}+\left[\mathrm{Al}(\mathrm{OH})_{n}\left(\mathrm{H}_{2} \mathrm{O}\right)_{6-n}\right]^{(3-n)+} \rightarrow\left[\mathrm{Si}-\mathrm{O}-\mathrm{Al}(\mathrm{OH})_{n-1}\left(\mathrm{H}_{2} \mathrm{O}\right)_{6-n}\right]^{(3-n)+}+\mathrm{H}_{2} \mathrm{O}
\end{gathered}
$$




$$
2\left[\mathrm{Al}(\mathrm{OH})_{n}\left(\mathrm{H}_{2} \mathrm{O}\right)_{6-n}\right]^{(3-n)+} \rightarrow\left[\left(\mathrm{H}_{2} \mathrm{O}\right)_{6-n}(\mathrm{OH})_{n-1} \mathrm{Al}-\mathrm{O}-\mathrm{Al}(\mathrm{OH})_{n-1}\left(\mathrm{H}_{2} \mathrm{O}\right)_{6-n}\right]^{2(3-n)+}+\mathrm{H}_{2} \mathrm{O}
$$

After heat treatment at a high temperature, AL samples have greater shrinkage than $\mathrm{AO}$ samples due to the dehydration condensation of $-\mathrm{OH}$, which can be identified by the decrease in Si-OH bonds in the FTIR spectra and the decreased SSA. By contrast, AO samples exhibited better thermal stability due to their stable chemical properties and the crystal phase of $\alpha-\mathrm{Al}_{2} \mathrm{O}_{3}$ particles. Thus, $\mathrm{Si}-\mathrm{OH}$ bonds do not react completely at $800{ }^{\circ} \mathrm{C}$ and $\mathrm{AO}$ samples show less shrinkage and higher SSA.

\section{Conclusions}

In this work, we applied an acid-base two-step sol-gel method for the preparation of high-temperature heat-resisting alumina-doped silica aerogels using TEOS, $\mathrm{AlCl}_{3} \cdot 6 \mathrm{H}_{2} \mathrm{O}$ and $\alpha-\mathrm{Al}_{2} \mathrm{O}_{3}$ powders as the precursors. Alumina-doped silica aerogels were facilely prepared by two methods: Physical mixing and creating a chemical compound. Although both methods enhanced the thermal stability of silica aerogels before $800^{\circ} \mathrm{C}$, the hydrolysis of $\mathrm{AlCl}_{3} \cdot 6 \mathrm{H}_{2} \mathrm{O}$ produces $\mathrm{Al}-\mathrm{OH}$ and promotes the dehydration reaction of $\mathrm{Si}-\mathrm{OH}$. This gave the AL samples higher shrinkage and lower SSA after heat treatment at $800^{\circ} \mathrm{C}$. On the contrary, the addition of $\alpha-\mathrm{Al}_{2} \mathrm{O}_{3}$ powders reduced the dehydration reaction of the silicon hydroxyl groups, and the $6.1 \mathrm{wt} . \% \alpha-\mathrm{Al}_{2} \mathrm{O}_{3}$ powders-doped sample exhibited the lowest linear shrinkage (11\%) and highest SSA $\left(1056 \mathrm{~m}^{2} / \mathrm{g}\right)$ after heat treatment at $800{ }^{\circ} \mathrm{C}$ for $1 \mathrm{~h}$. The heat resistance is expected to be further improved through the composition with fiber in order to satisfy industrial requirements. This simple and rapid method can effectively enhance the thermal stability of silica aerogels and facilitate the large-scale production of low-cost thermal insulation applications of silica-based aerogels from 600 to $1000{ }^{\circ} \mathrm{C}$.

\section{Materials and Methods}

\subsection{Raw Materials}

TEOS, aluminum chloride hexahydrate $\left(\mathrm{AlCl}_{3} \cdot 6 \mathrm{H}_{2} \mathrm{O}\right)$, ethanol, nitric acid $\left(\mathrm{HNO}_{3}\right.$, $68 \%$ ), ammonia $\left(\mathrm{NH}_{4} \mathrm{OH}, 25 \%\right.$ ) and $\alpha-\mathrm{Al}_{2} \mathrm{O}_{3}$ powders (with an average diameter of $\approx 30 \mathrm{~nm}$ ) were purchased from Sinopharm Chemical Reagent Corporation (Shanghai, China). Deionized water was applied in all experiments. All reagents were analytical grade and were used as received without further purification.

\subsection{Synthesis}

TEOS (30 mL), ethanol $(55 \mathrm{~mL})$, and deionized water $(5 \mathrm{~mL})$ were added into a glass beaker to obtain solution A. Different proportions of $\mathrm{AlCl}_{3} \cdot 6 \mathrm{H}_{2} \mathrm{O}$ or $\alpha-\mathrm{Al}_{2} \mathrm{O}_{3}$ powders were dissolved or dispersed into ethanol in order to obtain solution $\mathrm{B}$, which was added to solution A with vigorous stirring. Solution C comprised ethanol: $\mathrm{HNO}_{3}=9: 1$, which was added to adjust the $\mathrm{pH}$ value of the solution to $\mathrm{pH} 1-2$ with stirring for $20 \mathrm{~min}$. Solution D consisted of ethanol: $\mathrm{NH}_{4} \mathrm{OH}=9: 1$, which was added to adjust the solution to $\mathrm{pH}$ 6-7. After stirring for several minutes, the solution changed into a transparent gel with quiescence in room temperature for about $10 \mathrm{~min}$. Samples with the molar percentage of $\mathrm{Al} /(\mathrm{Al}+\mathrm{Si})=1,2,4,7,10 \%$ were denoted as AL1, AL2, AL4, AL7 and AL10 for $\mathrm{AlCl}_{3} \cdot 6 \mathrm{H}_{2} \mathrm{O}$ and $\mathrm{AO} 1, \mathrm{AO} 2, \mathrm{AO} 4, \mathrm{AO} 7$ and $\mathrm{AO} 10$ for $\alpha-\mathrm{Al}_{2} \mathrm{O}_{3}$ powders, respectively.

The wet gels aged for one day and the solvent was displaced with fresh ethanol for 3 days. The ethanol supercritical drying was carried out in an autoclave heated to $260^{\circ} \mathrm{C}$ and $10 \mathrm{MPa}$ with a heating rate of $1^{\circ} \mathrm{C} / \mathrm{min}$ and was held for $1 \mathrm{~h}$ at $260^{\circ} \mathrm{C}$. The ethanol in the autoclave was then emitted gradually with a decompression rate of about $2 \mathrm{MPa} / \mathrm{h}$. The obtained alumina-doped silica aerogels were heat-treated at 300, 400, 450, 500, 550, 600, $700,800,900$ and $1000{ }^{\circ} \mathrm{C}$ and the corresponding samples were denoted by adding the heat treatment as a suffix (e.g., AL4-300 and AO1-800).

\subsection{Characterization}

The linear shrinkage was calculated depending on the change in the cylinder diameters of the aerogels with an increment in temperature. The samples compared were the 
as-prepared aerogels derived from super critical drying process without any treatment. Bulk density was determined by the mass and volume of regular cylinders. The surface morphology was observed by scanning electron microscopy (ZEISS Gemini 300, Oberkochen, Germany). The chemical groups that remained in the samples were investigated by a Fourier transform infrared spectrometer (FTIR, TENSOR27, Bruker, Karlsruhe, Germany), and all samples were dispersed in dry $\mathrm{KBr}$ and pressed into a semitransparent slice for FTIR characterization. The crystal phase of the aerogels was analyzed by powder X-ray diffraction (XRD) with a Rigata/max-C diffractometer using $\mathrm{Cu}-\mathrm{K}_{\alpha}$ radiation (Rigaku Ultima IV, Tokyo, Japan). The specific surface area (SSA) and pore size distributions were obtained by a $\mathrm{N}_{2}$ adsorption analyzer (ASAP2460). Thermal conductivity was measured by thermal constant analyzer (Hotdisk TPS 2500, Uppsala, Sweden).

Author Contributions: Data curation, Z.Z.; Formal analysis, X.W.; Investigation, L.L.; Methodology, Y.W.; Project administration, J.S.; Supervision, J.S.; Visualization, X.W.; Writing-original draft, Y.W.; Writing-review \& editing, X.W. All authors have read and agreed to the published version of the manuscript.

Funding: This research was funded by the National Key Research and Development Program of China, grant number 2017YFA0204600.

Institutional Review Board Statement: Not applicable.

Informed Consent Statement: Not applicable.

Data Availability Statement: The data presented in this study are available on request from the corresponding author.

Conflicts of Interest: The authors declare no conflict of interest.

\section{References}

1. Despetis, F.; Calas-Etienne, S.; Etienne, P. Slow crack growth in silica aerogels: A review. J. Sol.-Gel Sci. Technol. 2019, 90, 20-27. [CrossRef]

2. Zhang, C.; Dai, C.; Zhang, H.; Peng, S.; Wei, X.; Hu, Y. Regeneration of mesoporous silica aerogel for hydrocarbon adsorption and recovery. Mar. Pollut. Bulletin. 2017, 122, 129-138. [CrossRef]

3. Parale, V.G.; Lee, K.Y.; Park, H.H. Flexible and transparent silica aerogels: An overview. J. Korean Ceram. Soc. 2017, 54, 184-199. [CrossRef]

4. He, Y.; Xie, T. A review of heat transfer models of nanoporous silica aerogel insulation material. Chin. Sci. Bull. 2015, 60, 137-163.

5. Pisal, A.A.; Rao, A.V. Comparative studies on the physical properties of TEOS, TMOS and $\mathrm{Na}_{2} \mathrm{SiO}_{3}$ based silica aerogels by ambient pressure drying method. J. Porous Mater. 2016, 23, 1547-1556. [CrossRef]

6. Reim, M.; Korner, W.; Manara, J.; Korder, S.; Arduini-Schuster, M.; Ebert, H.P.; Fricke, J. Silica aerogel granulate material for thermal insulation and daylighting. Sol. Energy 2005, 79, 131-139. [CrossRef]

7. Cao, S.L.; Yao, N.; Yeung, K.L. Synthesis of freestanding silica and titania-silica aerogels with ordered and disordered mesopores. J. Sol.-Gel Sci. Technol. 2008, 46, 323-333. [CrossRef]

8. Kaya, G.G.; Deveci, H. Synergistic effects of silica aerogels/xerogels on properties of polymer composites: A review. J. Ind. Eng. Chem. 2020, 89, 13-27. [CrossRef]

9. Hung, W.-C.; Horng, R.S.; Shia, R.-E. Investigation of thermal insulation performance of glass/carbon fiber-reinforced silica aerogel composites. J. Sol.-Gel Sci. Technol. 2021, 97, 414-421. [CrossRef]

10. Maleki, H.; Durães, L.; Portugal, A. An overview on silica aerogels synthesis and different mechanical reinforcing strategies. J. Non-Cryst. Solids 2014, 385, 55-74. [CrossRef]

11. Chen, H.; Zhang, Y.; Zhong, T.; Wu, Z.; Zhan, X.; Ye, J. Thermal insulation and hydrophobization of wood impregnated with silica aerogel powder. J. Wood Sci. 2020, 66, 1-11. [CrossRef]

12. Yay, B.; Gizli, N. A review on silica aerogels for $\mathrm{CO}_{2}$ capture applications. Pamukkale Univ. J. Eng. Sci. Pamukkale Univ. Muhendis. Bilimleri Derg. 2019, 25, 907-913. [CrossRef]

13. Jia, H.J.; Liu, S.; Mao, Z.Y.; Wang, D.J. Preparation and properties of the $\mathrm{Al}_{2} \mathrm{O}_{3}-\mathrm{SiO}_{2}$ aerogel/alumina framework composite. Ceram. Int. 2021, 47, 1466-1471. [CrossRef]

14. Peng, F.; Jiang, Y.; Feng, J.; Li, L.; Cai, H.; Feng, J. A facile method to fabricate monolithic alumina-silica aerogels with high surface areas and good mechanical properties. J. Eur. Ceram. Soc. 2020, 40, 2480-2488. [CrossRef]

15. Posada, L.F.; Carroll, M.K.; Anderson, A.M.; Bruno, B.A. Inclusion of Ceria in alumina- and silica-based aerogels for catalytic applications. J. Supercrit. Fluids 2019, 152, 104536. [CrossRef] 
16. Zou, W.B.; Wang, X.D.; Wu, Y.; Zou, L.P.; Zu, G.Q.; Chen, D.; Shen, J. Opacifier embedded and fiber reinforced alumina-based aerogel composites for ultra-high temperature thermal insulation. Ceram. Int. 2019, 45, 644-650. [CrossRef]

17. Zou, W.; Wang, X.; Wu, Y.; Zu, G.Q.; Zou, L.P.; Zhang, R.; Yao, X.; Shen, J. Highly thermally stable alumina-based aerogels modified by partially hydrolyzed aluminum tri-sec-butoxide. J. Sol-Gel Sci. Technol. 2017, 84, 507-514. [CrossRef]

18. Wu, X.; Shao, G.; Shen, X.; Cui, S.; Wang, L. Novel $\mathrm{Al}_{2} \mathrm{O}_{3}-\mathrm{SiO}_{2}$ composite aerogels with high specific surface area at elevated temperatures with different alumina/silica molar ratios prepared by a non-alkoxide sol-gel method. RSC Adv. 2016, 6, 5611-5620. [CrossRef]

19. Zhang, R.B.; Ye, C.S.; Wang, B.L. Novel $\mathrm{Al}_{2} \mathrm{O}_{3}-\mathrm{SiO}_{2}$ aerogel/porous zirconia composite with ultra-low thermal conductivity. J. Porous Mater. 2018, 25, 171-178. [CrossRef]

20. Zu, G.Q.; Shen, J.; Zou, L.P.; Zou, W.B.; Guan, D.Y.; Wu, Y.; Zhang, Y.W. Highly thermally stable zirconia/silica composite aerogels prepared by supercritical deposition. Microporous Mesoporous Mat. 2017, 238, 90-96. [CrossRef]

21. Long, J.W.; Chervin, C.N.; Balow, R.B.; Jeon, S.; Miller, J.B.; Helms, M.E.; Owrutsky, J.C.; Rolison, D.R.; Fears, K.P. Zirconia-based aerogels for sorption and degradation of dimethyl methylphosphonate. Ind. Eng. Chem. Res. 2020, 59, 19584-19592. [CrossRef]

22. Gao, H.B.; Zhang, Z.Y.; Shi, Z.Y.; Zhang, J.Z.; Zhi, M.J.; Hong, Z.L. Synthesis of high-temperature resistant monolithic zirconiabased aerogel via facile water glass assisted sol-gel method. J. Sol.-Gel Sci. Technol. 2018, 85, 567-573. [CrossRef]

23. Yu, Y.X.; Zhu, M.W. Preparation and characterization of highly spherical silica-titania aerogel beads with high surface area. Cailiao Gongcheng-J. Mater. Eng. 2017, 45, 7-11.

24. Wang, X.K.; Liu, J.X.; Shi, F.; Liu, S.H.; Feng, X.; Bao, L. Influences of heat-treatment on the microstructure and properties of silica-titania composite aerogels. J. Porous Mater. 2014, 21, 293-301. [CrossRef]

25. An, L.; Petit, D.; Di Luigi, M.; Sheng, A.; Huang, Y.; Hu, Y.; Li, Z.; Ren, S. Reflective paint consisting of mesoporous silica aerogel and titania nanoparticles for thermal management. ACS Appl. Nano Mater. 2021, 4, 6357-6363. [CrossRef]

26. Yoda, S.; Otake, K.; Takebayashi, Y.; Sugeta, T.; Sato, T. Effects of supercritical impregnation conditions on the properties of silica-titania aerogels. J. Non-Cryst. Solids 2001, 285, 8-12. [CrossRef]

27. Zu, G.Q.; Shen, J.; Zou, L.P.; Wang, W.Q.; Lian, Y.; Zhang, Z.H.; Du, A. Nanoengineering super heat-resistant, strong alumina aerogels. Chem. Mater. 2013, 25, 4757-4764. [CrossRef]

28. Wang, X.; Du, Y.; Yang, H.; Tian, S.; Ge, Q.; Huang, S.; Wang, M. Removal of chloride ions from acidic solution with antimony oxides. J. Ind. Eng. Chem. 2021, 93, 170-175. [CrossRef]

29. Sun, F.; Liu, W.; Yan, K.; Yishuai, E. Removal of chloride ion from desulfurization wastewater by ion-exchange resin. Inorg. Chem. Ind. 2019, 51, 45-48.

30. Yang, C.; Yang, G.; Shi, Y.; Chen, S. Study on electrosorption removal of chloride ion from reclaimed water. Adv. Mater. Res. 2012, 356-360, 2015-2019. [CrossRef]

31. Sun, J. Selective sodium removal from lithium chloride brine with novel inorganic ion exchanger. Bull. Chem. Soc. Ethiop. 2013, 27, 241-248. [CrossRef]

32. Wu, X.D.; Ding, J.; Kong, Y.; Sun, Z.; Shao, G.F.; Li, B.Y.; Wu, J.; Zhong, Y.; Shen, X.D.; Cui, S. Synthesis of a novel three-dimensional $\mathrm{Na}_{2} \mathrm{SO}_{4} @ \mathrm{SiO}_{2} @ \mathrm{Al}_{2} \mathrm{O}_{3}-\mathrm{SiO}_{2}$ phase change material doped aerogel composite with high thermal resistance and latent heat. Ceram. Int. 2018, 44, 21855-21865. [CrossRef]

33. Chen, H.; Sui, X.Y.; Zhou, C.L.; Wang, C.H.; Liu, F.T. Preparation and characterization of monolithic $\mathrm{Al}_{2} \mathrm{O}_{3}-\mathrm{SiO}_{2}$ aerogel. J. Ceram. Soc. Jpn. 2016, 124, 442-447. [CrossRef]

34. Lei, Y.F.; Chen, X.H.; Song, H.H.; Hu, Z.J.; Cao, B. Improvement of thermal insulation performance of silica aerogels by $\mathrm{Al}_{2} \mathrm{O}_{3}$ powders doping. Ceram. Int. 2017, 43, 10799-10804. [CrossRef]

35. Zu, G.; Shen, J.; Wang, W.; Zou, L.; Lian, Y.; Zhang, Z. Synthesis and thermal behavior of high-surface-area monolithic alumina aerogels. Rare Met. Mat. Eng. 2016, 45, 522-529.

36. Tang, X.B.; Sun, A.H.; Chu, C.Y.; Yu, M.L.; Ma, S.; Cheng, Y.C.; Guo, J.J.; Xu, G.J. A novel silica nanowire-silica composite aerogels dried at ambient pressure. Mater. Des. 2017, 115, 415-421. [CrossRef]

37. Zu, G.; Shen, J.; Wei, X.; Ni, X.; Zhang, Z.; Wang, J.; Liu, G. Preparation and characterization of monolithic alumina aerogels. J. Non-Cryst. Solids 2011, 357, 2903-2906. [CrossRef]

38. Horiuchi, T.; Osaki, T.; Sugiyama, T.; Masuda, H.; Horio, M.; Suzuki, K.; Mori, T.; Sago, T. High-surface-area alumina aerogel at elevated-temperatures. J. Chem. Soc. -Faraday Trans. 1994, 90, 2573-2578. [CrossRef] 